\title{
Editorial \\ Climate Change and Anthropogenic Impact on Coastal Environments
}

\author{
Monica Bini 1,2,3,*(D) and Veronica Rossi ${ }^{4, *(D)}$ \\ 1 Department of Earth Sciences, University of Pisa, Via S. Maria 53, 56126 Pisa, Italy \\ 2 Centre for Climatic Change Impact (CIRSEC), University of Pisa, Via del Borghetto 80, 56124 Pisa, Italy \\ 3 Istituto Nazionale di Geofisica e Vulcanologia (INGV), Sez. Pisa, via Cesare Battisti 53, 56125 Pisa, Italy \\ 4 Department of Biological, Geological and Environmental Sciences, University of Bologna, Via Zamboni 67, \\ 40126 Bologna, Italy \\ * Correspondence: monica.bini@unipi.it (M.B.); veronica.rossi4@unibo.it (V.R.)
}

Citation: Bini, M.; Rossi, V. Climate Change and Anthropogenic Impact on Coastal Environments. Water 2021, 13, 1182. https://doi.org/10.3390/ w13091182

Received: 15 April 2021

Accepted: 22 April 2021

Published: 25 April 2021

Publisher's Note: MDPI stays neutral with regard to jurisdictional claims in published maps and institutional affiliations.

Copyright: (C) 2021 by the authors. Licensee MDPI, Basel, Switzerland. This article is an open access article distributed under the terms and conditions of the Creative Commons Attribution (CC BY) license (https:// creativecommons.org/licenses/by/ $4.0 /)$.

\section{Introduction}

Coastal-transitional areas, including delta plains, strandplains, lagoons, embayments, salt marshes, and mangroves, are some of the most valuable global resources in terms of both socioeconomic interest and cultural-natural heritage. However, these areas, placed at the border between land and sea, are extremely sensitive to the combined effect of several natural and anthropogenic factors, resulting in them inevitably being at the forefront of the threat of global change. In this respect, approximately $28,000 \mathrm{~km}^{2}$ of global coastline was eroded between 1984 and 2015, about twice as much as that formed by accumulation processes [1]. Besides coastal erosion and loss of territory, severe impacts on environments and ecosystems are ascribable to the accumulation of anthropogenic debris, contaminants, and algal masses (e.g., [2-6]). According to the Fifth Assessment Report of the Intergovernmental Panel on Climate Change-IPCC, by 2100 the health of coastal zones will worsen as a result of the gradual rise in sea-level and due to the possible increase in frequency and intensity of extreme events. Both phenomena are related to global warming that, in turn, is very likely connected with the use of fossil fuels and the increased human pressure on the Earth [7]. Unfortunately, the IPCC projections appear too optimistic since the global sea-level is likely to rise considerably (up to $1.35 \mathrm{~m}$ ) and more rapidly than what has been forecast so far. Indeed current predictions suffer from the limited amount of information concerning changes in ice-sheet volumes and, specifically, data on the melt-off rate of Antarctica are considered crucial for robust model testing and analysis [8]. All these elements, contextualized into the natural dynamic equilibrium of coasts, may put at risk the future of many human lives, cities, and services, as hundreds of millions of people currently live and take advantage of the coastal zone (e.g., [9,10]).

The urgent need for good practices, aimed at the preservation and sustainable exploitation of natural resources, has increased the interest of the scientific community in the complex dynamics and resilience strategies of low-lying coastal-delta plains and rocky coastal sectors. In this regard, the high sensitivity of coastal-transitional environments to climate-relative sea level (RSL) oscillations and anthropogenic activities, operating at various timescales (from millennial to sub-centennial), makes them exceptional geological archives storing critical information about present and past processes alike.

This Special Issue focuses on three main aspects of coastal-transitional systems, namely, complexity, vulnerability, and sensitivity; underlining the key role played by highly integrated multidisciplinary approaches to unraveling the records of the present and the past. This Issue aims to illustrate a set of recent advances in field and remote sensing observations, laboratory techniques, numerical modelling, and statistical analyses applied to the quantitative monitoring of coastal areas and the reconstruction of past landscape dynamics under changing climate-RSL conditions. 


\section{Content of the Special Issue}

If supported by a multidisciplinary approach, lessons from the past and the present are known to be strategic for a robust estimation of future scenarios and the identification of the main processes and drivers, with a high degree of confidence (e.g., [11-17]). This Special Issue offers a wide spectrum of contributions, where different methodologies have been used to improve our knowledge of various coastal sectors facing the Atlantic Ocean and the western Mediterranean Sea. The study areas include sites ranging from the Mexican Caribbean, Patagonian Argentina, the eastern region of the United States, and the Ligurian, Tyrrhenian, and Adriatic coasts of Italy.

The proposed nine manuscripts cover three fundamental topics, highlighting different aspects through an original angle of investigation: (i) the identification of evolution trajectories and related controlling factors during the recent past (i.e., the late Quaternary period); (ii) the monitoring of coastal processes over short time periods (i.e., years); and (iii) the quality status of environments and ecosystems under natural and/or human-related (e.g., pollution) stress conditions.

The first group of articles deals with the past sedimentary and palaeobiological record of the coastal zone and the wide range of information that can be extracted. Specifically, Rossi et al. have documented the importance of a multidisciplinary approach to reconstructing the late Quaternary evolution trends of depositional environments and vegetation patterns of rocky coastal tracts. The application of a multi-proxy (ostracoda, foraminifera, pollen, and radiocarbon), facies-based analysis on the subsurface of the Gulf of La Spezia (NW Italy, Ligurian Sea) allowed the identification of past landscapes and related forcing factors, including climate, relative sea-level oscillations at Milankovitch and sub-Milankovitch scales, and inherited morphologies.

Christie et al. have underlined the crucial role played by age-depth models for better understanding the climatic and geological information stored in the coastal sedimentary archives. The authors have combined new and published pollen data from eight coastal wetlands (salt marshes and mangroves) along the Atlantic coast of the United States, from Florida to Connecticut, to define the age and uncertainty of a series of pollen chronohorizons over the last 500 years. The results of this study demonstrate that the inclusion of pollen chronohorizons in age-depth models can be helpful in situations where other age markers have proven to be sparse or largely uncertain in age.

Another group of fossils (molluscs) was used by Borretto et al. to obtain quantitative data on the climate change effects at a regional scale (SW Atlantic Ocean) over the Holocene. The authors have interpreted the stable isotope composition $\left(\delta^{18} \mathrm{O}\right)$ of living and fossil Mytilidae shells, collected from the gulf area of Bahía Camarones (Chubut, Argentina), as indicative of sea temperature changes. These isotopic values suggest cooler seawater before $6.1 \mathrm{cal} \mathrm{ka} \mathrm{BP}$, with a maximum possible temperature shift of about $5^{\circ} \mathrm{C}$. A possible explanation for this change is the northward position of the confluence zone of the Falkland and Brazilian currents.

Moving from past to present conditions, the second set of articles document progress in the application of remote sensing techniques for the monitoring of coastal processes and environments. Luppichini et al. have addressed the issue of shoreline definition by comparing the different methods available and testing them on the Pisa coastal plain (NW Italy, Ligurian Sea). They have suggested a new and valid beach topography-based algorithm (now also officially recognized in the qgis plugin repository). Chavez et al. have applied satellite image analysis to understand the dynamics of the Sargassum influx in the sea off the Mexican-Caribbean coast (western-central Atlantic Ocean) over the past seven years (2014-2020). The authors have also evaluated the impact on ecosystems (local flora and fauna) and society, proposing strategies to mitigate the negative effects of massive Sargassum influxes.

The contributions by Barbieri et al., Pasquetti et al., Losada Ros et al., and Merlino et al. compose the third group of articles, which deal with the quality status evaluation of coastal areas and good practices in coastal management. Barbieri et al. have faced the issue 
of defining reference conditions in naturally stressed transitional settings, through the analysis of the palaeoecological quality status (PalaeoEcoQs) of Holocene lagoon and paludal environments, encased within the shallow subsurface of the Po coastal plain (NE Italy, Adriatic Sea). Values of foraminiferal species diversity and Foram-AMBI indices, accompanied by multivariate analyses, demonstrate the importance of a site-specific palaeobiological approach to exploring the high ranges of variability of such environments.

Human activities, superimposed on the natural short and long (palaeo-)environmental gradients, can lead to a dramatic degradation of the quality status of coastal areas. In particular, pollutants represent a great threat for ecosystems. The importance of studying heavy metals distribution, concentration, and effects on benthos has been stressed by Pasquetti et al. and by Losada Ros et al., respectively. Pasquetti et al. have defined the geochemical baseline of southern Tuscany (NW Italy), an important metallogenic district hosting relevant S-polymetallic deposits intensely exploited for centuries, before human intervention. They have evaluated the potential dispersion of these harmful elements in the Orbetello lagoon (Tyrrhenian Sea). Losada Ros et al. have tested the acute effect of cadmium-Cd, one of the most dangerous pollutants for marine organisms, on the benthic foraminiferal species Ammonia cf. parkinsoniana via a bioassay experiment. This study reveals the potential threat of $\mathrm{Cd}$, even at very low concentrations, to an important component of the coastal meiofauna (A. cf. parkinsoniana), by providing complementary information to field observations and quality status evaluations.

Microplastics (e.g., [18]) represent another widespread form of pollution, which is now widely recognized. Merlino et al. have tested and validated a Raman portable instrument for in situ analyses of the polymeric nature of large microplastics (LMPs) in the Pelagos Sanctuary, an international protected area along the north-western Italian coastline. The study demonstrates how that type of polymer influences the degree of fragmentation and underlines the necessity to further investigate the mechanisms leading to the production and dispersion of MPs in coastal areas.

All the papers published in this issue emphasize on the need for robust field and laboratory data, framed in an integrated approach, to improve our knowledge about coastal dynamic processes and to support models concerning future evolution trends, and the sustainable development of such sensitive territories. The different contributions underline the importance of precise methodologies for solving specific problems, but they also highlight the urgency for shared strategies designed to preserve a precious environment increasingly threatened by both anthropogenic impacts and climate change.

Funding: This research received no external funding.

Acknowledgments: The guest editors of the Special Issue wish to thank the journal editors, all authors submitting papers and the referees who have contributed to the quality improvement of the issue. Part of this study has been developed within the framework of the project "Cambiamenti globali e impatti locali: conoscenza e consapevolezza per uno sviluppo sostenibile della pianura apuo-versiliese" awarded to M.B. and funded by the Fondazione Cassa di Risparmio di Lucca, call 2019 and "PRA-2018-41 Georisorse e Ambiente" funded by the University of Pisa.

Conflicts of Interest: The authors declare no conflict of interest.

\section{References}

1. Mentaschi, L.; Vousdoukas, M.I.; Pekel, J.F.; Voukouvalas, E.; Feyen, L. Global long-term observations of coastal erosion and accretion. Sci. Rep. 2018, 8, 1-11. [CrossRef] [PubMed]

2. Derraik, J.G.B. The pollution of the marine environment by plastic debris: A review. Mar. Pollut. Bull. 2002, 44, 842-852. [CrossRef]

3. Berdalet, E.; Montresor, M.; Reguera, B.; Roy, S.; Yamazaki, H.; Cembella, A.; Raine, R. Harmful algal blooms in fjords, coastal embayments, and stratified systems. Oceanography 2017, 30, 46-57. [CrossRef]

4. Berdalet, E.; Tester, P.A.; Chinain, M.; Fraga, S.; Lemée, R.; Litaker, W.; Penna, A.; Usup, G.; Vila, M.; Zingone, A. Harmful algal blooms in benthic systems. Oceanography 2017, 30, 36-45. [CrossRef]

5. Lebreton, L.C.M.; van der Zwet, J.; Damsteeg, J.W.; Slat, B.; Andrady, A.; Reisser, J. River plastic emissions to the world's oceans. Nat. Commun. 2017, 8, 1-10. [CrossRef] [PubMed] 
6. Roman, L.; Hardesty, B.D.; Leonard, G.H.; Pragnell-Raasch, H.; Mallos, N.; Campbell, I.; Wilcox, C. A global assessment of the relationship between anthropogenic debris on land and the seafloor. Environ. Pollut. 2020, 264, 114663. [CrossRef] [PubMed]

7. IPCC. Climate Change 2013: The Physical Science Basis; Stocker, T.F., Qin, D., Plattner, G.-K., Tignor, M.M.B., Allen, S.K., Boschung, J., Nauels, A., Xia, Y., Bex, V., Midgley, P.M., Eds.; Cambridge University Press: Cambridge, UK, 2013.

8. Rignot, E.; Mouginot, J.; Scheuchl, B.; van den Broeke, M.; van Wessem, M.J.; Morlighem, M. Four decades of Antarctic ice sheet mass balance from 1979-2017. Proc. Natl. Acad. Sci. USA 2019, 116, 1095-1103. [CrossRef] [PubMed]

9. Neumann, B.; Vafeidis, A.T.; Zimmermann, J.; Nicholls, R.J. Future coastal population growth and exposure to sea-level rise and coastal flooding-A global assessment. PLoS ONE 2015, 10, e0118571. [CrossRef] [PubMed]

10. Cramer, W.; Guiot, J.; Fader, M.; Garrabou, J.; Gattuso, J.P.; Iglesias, A.; Lange, M.A.; Lionello, P.; Llasat, M.C.; Paz, S.; et al. Climate change and interconnected risks to sustainable development in the Mediterranean. Nat. Clim. Chang. 2018, 8, 972-980. [CrossRef]

11. Woodroffe, C.D.; Murray-Wallace, C.V. Sea-level rise and coastal change: The past as a guide to the future. Quat. Sci. Rev. 2012, 54, 4-11. [CrossRef]

12. Costas, S.; Ferreira, Ó.; Plomaritis, T.A.; Leorri, E. Coastal barrier stratigraphy for Holocene high-resolution sea-level reconstruction. Sci. Rep. 2016, 6, 1-12. [CrossRef] [PubMed]

13. Armenio, E.; de Serio, F.; Mossa, M.; Petrillo, A.F. Coastline evolution based on statistical analysis and modeling. Nat. Hazards Earth Syst. Sci. 2019, 19, 1937-1953. [CrossRef]

14. Kulp, S.A.; Strauss, B.H. New elevation data triple estimates of global vulnerability to sea-level rise and coastal flooding. Nat. Commun. 2019, 10, 1-12.

15. Melet, A.; Teatini, P.; Le Cozannet, G.; Jamet, C.; Conversi, A.; Benveniste, J.; Almar, R. Earth Observations for Monitoring Marine Coastal Hazards and Their Drivers; Springer: Berlin/Heidelberg, Germany, 2020; Volume 41, ISBN 0123456789.

16. Wiberg, P.L.; Fagherazzi, S.; Kirwan, M.L. Improving predictions of salt marsh evolution through better integration of data and models. Ann. Rev. Mar. Sci. 2020, 12, 389-413. [CrossRef] [PubMed]

17. Tornqvist, T.E.; Cahoon, D.R.; Morris, J.T.; Day, J.W. Coastal wetland resilience, accelerated sea-level rise, and the importance of timescale. AGU Adv. 2021, 2, 1-9. [CrossRef]

18. Díaz-Mendoza, C.; Mouthon-Bello, J.; Pérez-Herrera, N.L.; Escobar-Díaz, S.M. Plastics and microplastics, effects on marine coastal areas: A review. Environ. Sci. Pollut. Res. 2020, 27, 39913-39922. [CrossRef] [PubMed] 